\title{
A NEW MISSISSIPPIAN TETRAPOD FROM FIFE, SCOTLAND, AND ITS ENVIRONMENTAL CONTEXT
}

\author{
by TIMOTHY R. SMITHSON ${ }^{1}$ (D) MICHAEL A. E. BROWNE ${ }^{2}$, SARAH J DAVIES $^{3}$, \\ JOHN E. A. MARSHALL ${ }^{4}$, DAVID MILLWARD ${ }^{2}$, STIG A. WALSH $^{5}$ and \\ JENNIFER A. CLACK ${ }^{1}$ \\ ${ }^{1}$ University Museum of Zoology, Downing Street, Cambridge, CB2 3EJ, UK; ts556@cam.ac.uk \\ ${ }^{2}$ British Geological Survey, The Lyell Centre, Research Avenue South, Edinburgh, EH14 4AP, UK \\ ${ }^{3}$ Department of Geology, University of Leicester, Leicester, LE1 7RH, UK \\ ${ }^{4}$ School of Ocean \& Earth Science, National Oceanography Centre, University of Southampton, Waterfront Campus, European Way, Southampton, SO14 3ZH, UK \\ ${ }^{5}$ Department of Natural Sciences, National Museums Scotland, Chambers Street, Edinburgh, EH1 1JF, UK
}

Typescript received 11 April 2017; accepted in revised form 29 June 2017

\begin{abstract}
The Visean stage of the Mississippian was a time of rapid tetrapod diversification which marks the earliest appearance of temnospondyls, microsaurs and the limbless aistopods. Tetrapod finds from this stage are very rare and only a dozen sites are known worldwide. Here we announce the discovery of a new Visean site in Fife, Scotland, of Asbian age, and from it describe a new species of the baphetoid Spathicephalus. These specimens represent the oldest known baphetoid by three million years, yet belong to the most specialized members of the clade. Unlike typical baphetoids with large marginal teeth and palatal fangs
\end{abstract}

characteristic of early tetrapods, spathicephalids had very broad flattened heads with a dentition consisting of a large number of small, uniform teeth. Spathicephalids were probably one of the earliest tetrapod groups to use suction feeding on small, aquatic prey. Palynological and sedimentological analysis indicates that the new fossil bed was deposited in a large, stratified, freshwater lake that became increasingly saline.

Key words: Mississippian, Visean, Asbian, tetrapod, Spathicephalidae.
Although recent discoveries in the earliest Carboniferous have revealed that tetrapod diversification was well established by the Tournaisian (Smithson et al. 2012; Anderson et al. 2015; Clack et al. 2016) the predominant members of the Carboniferous tetrapod fauna, the aistopods, anthracosaurs, microsaurs and temnospondyls, have not been found among them: these first appear in the Visean, 10 myr later. Nevertheless, phylogenetic analysis of this new fauna retrieved two stem amphibians and one possible stem amniote (Clack et al. 2016) indicating an earlier origin for these major clades. The previous record was from the East Kirkton Quarry, West Lothian, Scotland (Wood et al. 1985). Although some discoveries have been made in the Visean of Scotland (Wood et al. 1985; Paton et al. 1999), USA (Bolt et al. 1988) and Australia (Thulborn et al. 1996) Visean tetrapod finds remain very rare, with only a dozen sites known worldwide. Those finds hint that the Visean was a time of morphological innovation among tetrapods, with limbless forms and unusual cranial morphologies appearing for the first time.

One group that first appears in the Visean, the baphetoids, shows diverse dentitions and a unique cranial morphology. With skulls up to $30 \mathrm{~cm}$ long, they are characterized by openings on the skull roof of uncertain function, the antorbital fenestrae (Clack \& Milner 2015). The two recognized clades (Milner et al. 2009) are the baphetids, with crocodile-like skulls, large marginal teeth and palatal tusks, and a posterior medial process demarcating the anterolateral edge of the orbit (character 7 of Milner et al. 2009) and the spathicephalids with broad, flattened spade-shaped skulls and numerous tiny teeth (Milner et al. 2009); the latter appears to be the more specialized. Baphetids are known from the Visean until the late Pennsylvanian but spathicephalid specimens have been found previously only in the Serpukhovian, at two sites in Scotland and one in Nova Scotia (Baird 1962; Beaumont \& Smithson 1998). The origins of these two clades and their cranial and dental modifications remain unknown, but presumably were much earlier.

We report the discovery and briefly describe a new spathicephalid and its environmental setting from a recently discovered vertebrate-bearing site in the Visean of Fife, Scotland. This specialized taxon is the earliest known member of the baphetoids. 


\section{GEOLOGICAL SETTING}

The material was discovered in a richly fossiliferous bed in the upper part of the Anstruther Formation (Fig. 1) exposed in the intertidal zone of the East Fife coast. The Anstruther Formation consists of at least $810 \mathrm{~m}$ of siltstone, cross-bedded sandstone, thin beds of non-marine limestone, dolostone and ironstone, and a few seat-earth palaeosols and thin coals (Forsyth \& Chisholm 1977; Waters et al. 2011). The new fossil bed is a thin $(9 \mathrm{~cm})$ ferroan dolostone (see below) within a 1-2 m-thick succession of dark grey siltstone under- and overlain by sharpbased, cross-bedded fine to medium grained sandstone (Fig. 1C). The fossil bed is exposed for at least $80 \mathrm{~m}$ along the shore and plant and vertebrate remains have been collected along its length. Vertebrate, plant and shelly fossils have also been found in the sedimentary rocks above and below this horizon. Two samples taken from grey siltstones immediately below the fossil bed contain a rich spore assemblage (see below). These data show that the beds are within the upper part of the tessellatus-campyloptera (TC) palynozone and are of Asbian age (Fig. 1).

\section{MATERIAL AND METHOD}

The new tetrapod material consists of a weathered skull and right mandible (Fig. 2A, B). The skull is exposed in ventral view. Much of the bone is missing but the dermal ornament and the course of sutures and lateral line canals on the skull are clearly visible in the natural mould. The poorly preserved mandible was broken post mortem: the anterior third is preserved in ventral view, the posterior two-thirds in mesial view. The matrix is very hard and insoluble in weak organic acids. No preparation of the fossils has yet been undertaken apart from the removal by mounted needle of encrusting barnacles.

A sample of the fossil bed was cut with a rock saw, and ground to give a smooth surface. This was scanned at 1600 dpi using an Epson Perfection 3200 photo scanner. An ultra-thin $(20 \mu \mathrm{m})$ uncovered and polished thin section was made at the University of Leicester. The thin section was scanned using an Epson Perfection V750 Pro to reveal the fabric of the sample and then examined using an Olympus $\mathrm{BH}-2$ petrographic microscope fitted with a Canon EOS 5D camera. The thin section was also examined on a Hitachi S-6300N Environmental Scanning Electron Microscope, and an Oxford INCA 350 EDX system was used to determine the elements present.

Palynological analysis was conducted on two samples from immediately below the fossil bed. These were labelled Fife $1 \& 2$. They were initially processed using standard palynological techniques of $30 \% \mathrm{HCl}$ to remove any carbonates, followed by decant washing to neutral. They were then demineralized in $60 \%$ HF followed by decant washing to neutral and sieved at $15 \mu \mathrm{m}$. The samples were then placed in glass beakers and briefly boiled in $30 \% \mathrm{HCl}$ to dissolve neoformed fluorides that were then removed by diluting into a large volume of water and resieving. The kerogen residues were then vialed and a small quantity mounted as a strew slide in Elvacite 2044. One of these (Fife 2 ) contained very few obvious spores, whereas Fife 1 was exceedingly spore rich but almost entirely comprising Lycospora pusilla. This sample was then cleaned of amorphous organic matter (AOM) with a $30 \mathrm{~s}$ treatment with a Sonics \& Materials ultrasonic probe followed by resieving at $15 \mu \mathrm{m}$. The AOM preferentially fragments through the action of the probe and can be removed as a smaller size fraction. The sample was then split into size fractions by sieving first at $50 \mu \mathrm{m}$ and then $100 \mu \mathrm{m}$. The sub-50 $\mu \mathrm{m}$ fraction contained most of the Lycospora. The $<50 \mu \mathrm{m}$ and $50-100 \mu \mathrm{m}$ fractions contained a greater diversity of diagnostic spores and 2 slides were logged from each of these fractions. The quantitative count (Table 1) was made of the original $>15 \mu \mathrm{m}$ ultrasonically cleaned fraction.

The tetrapod specimens and the samples used in the sedimentological analysis are accessioned in National Museums Scotland. The palynomorphs are housed at the University of Southampton.

\section{SYSTEMATIC PALAEONTOLOGY}

\author{
TETRAPODA Goodrich, 1930 \\ BAPHETOIDEA Cope, 1875 sensu Milner \& Lindsay, 1998 \\ SPATHICEPHALIDAE Beaumont, 1977
}

Genus SPATHICEPHALUS Watson, 1929

Type species. Spathicephalus mirus Watson, 1929.

Diagnosis. Emended diagnosis (after Beaumont \& Smithson 1998). Baphetoid characterized by the following

FIG. 1. Mississippian geology and tetrapod sites in Scotland. A, Visean tetrapod localities in Scotland, including the new East Fife finds. B, Visean stratigraphy in Scotland with horizons of known tetrapods (see text for references). The approximate horizon of the East Fife locality is shown. C, sedimentary log for the Anstruther Formation at the East Fife coast locality. Abbreviations of the Visean tetrapod localities: B, Burdiehouse, Edinburgh; Bx, Broxburn; C, new locality; Ch, Cheese Bay, Gullane; E, East Kirkton; G, Gilmerton, Edinburgh; In, Inchkeith; P, Pitcorthie, Fife; S, Straiton, Edinburgh; W, Wardie, Edinburgh. Details of each locality can be found in Smithson (1985), Wood et al. (1985) and Paton et al. (1999). Colour online. 
B
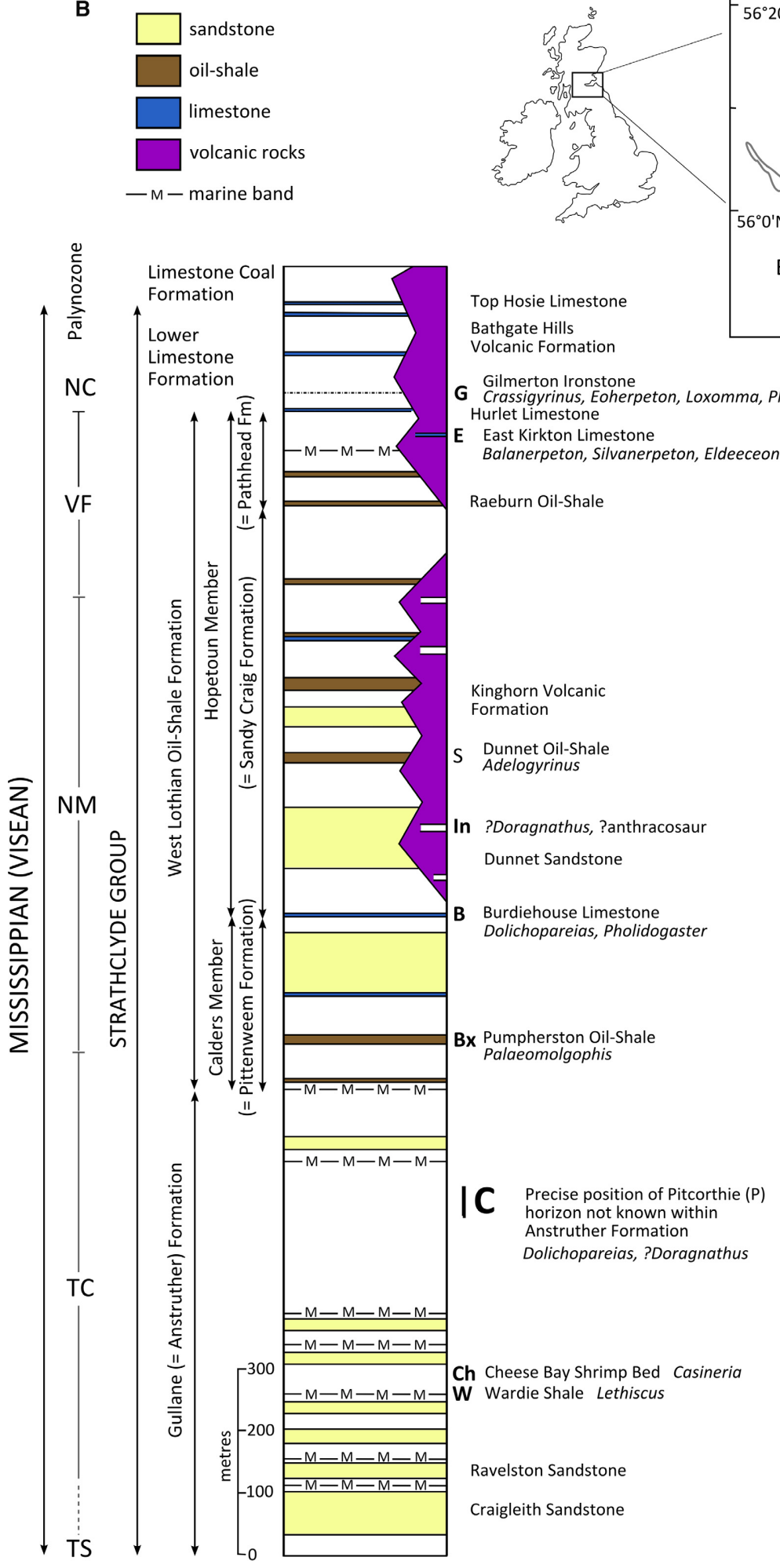

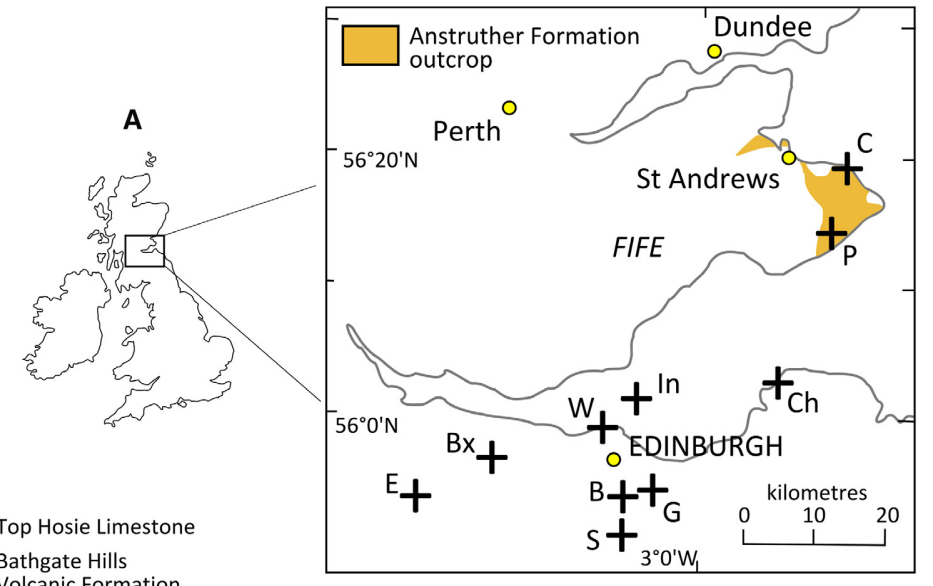

East Kirkton Limestone
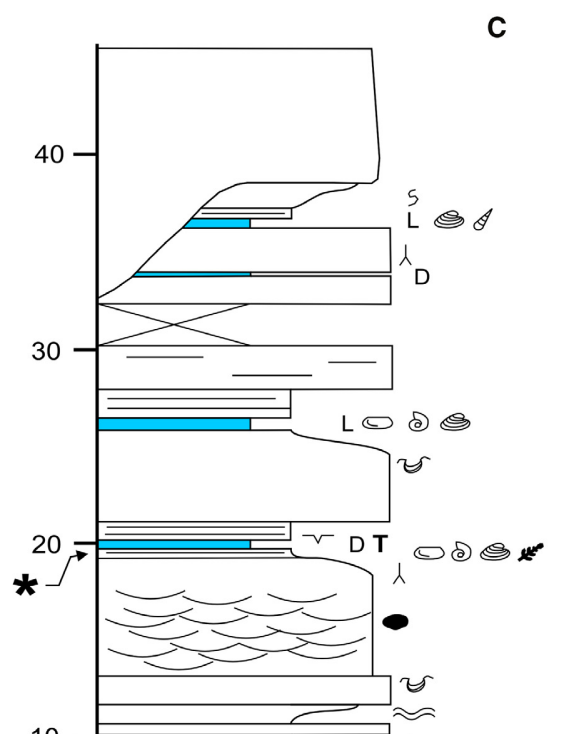

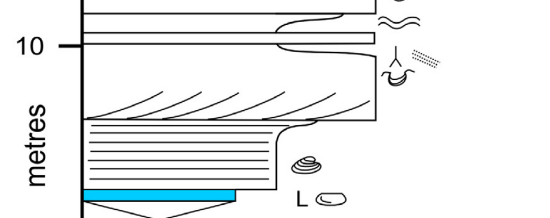

0

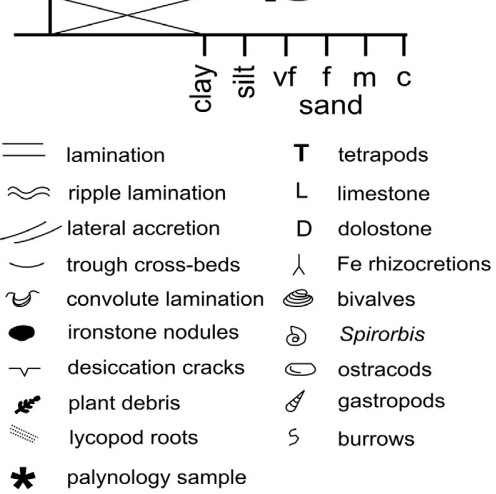




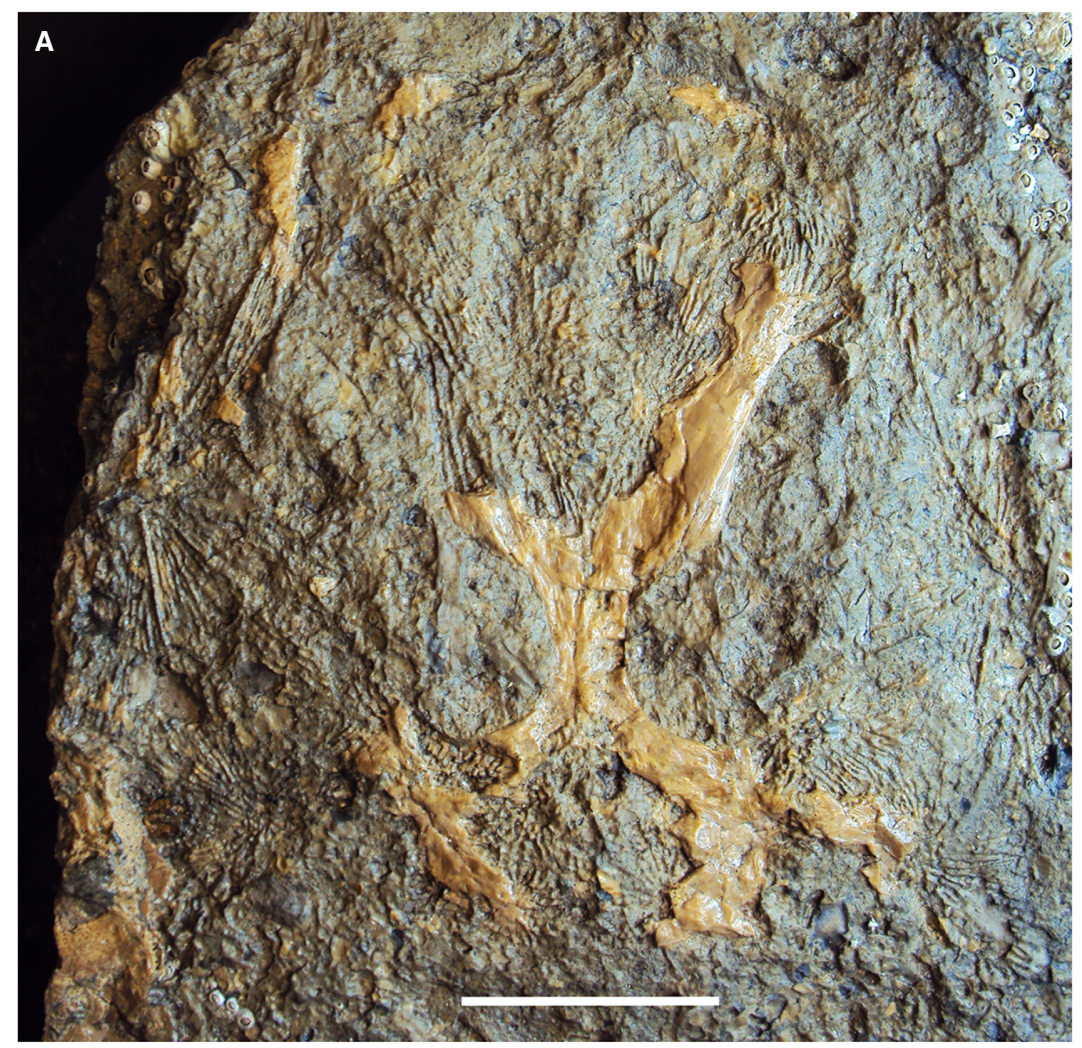

FIG. 2. Spathicephalus marsdeni sp. nov. A, skull roof NMS G 2015.37.1. B, left mandible NMS G 2015.37.2. Scale bars represent $30 \mathrm{~mm}$. Colour online.

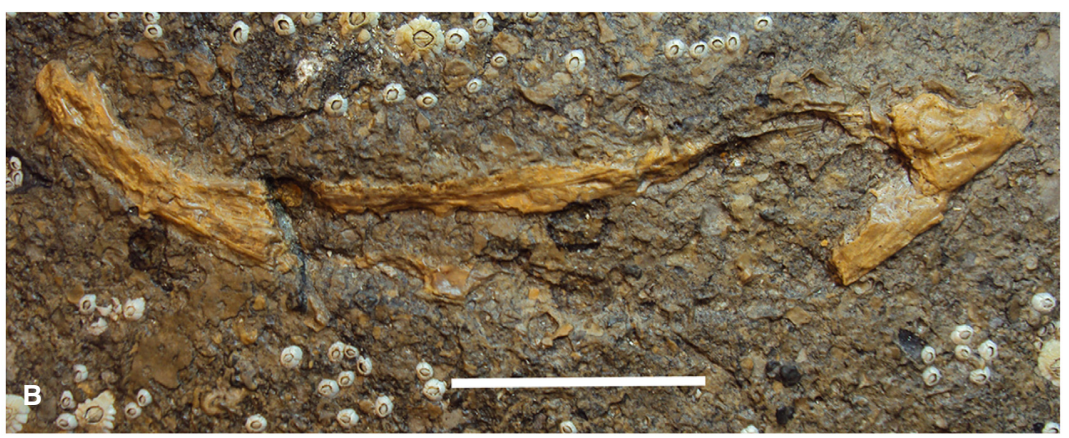

synapomorphies: broad, squarish skull outline; skull length and breadth almost equal; orbits close to the midline and far back in the skull; frontals enter orbit margin, preventing contact between prefrontal and postfrontal; skull table extremely short representing less than $20 \%$ of skull length, and twice as wide as long; premaxillary, maxillary and dentary teeth small, numerous and chiselshaped; the vomer and parasymphysial plate bear a row of smaller teeth; no denticles on palatal bones or coronoids; pterygoids, vomers and parasphenoid ornamented with fine ridges and pits; quadrate ramus of the pterygoid short and the jaw articulation almost in line with the occiput; no post-temporal fossae. It also shares with some baphetids the following characters that are derived with respect to the plesiomorphic baphetoid condition:
TABLE 1. Quantitative count of palynomorphs in the $>15 \mu \mathrm{m}$ ultrasonically cleaned fraction (total count 320).

\begin{tabular}{lcr}
\hline & Count & $\%$ \\
\hline Anapiculatisporites baccatus & 4 & 1 \\
Calamospora breviradiata & 3 & \\
Colatisporites decorus & 2 & \\
Granulatisporites microgranifer & 1 & \\
Lycospora noctuina & 3 & \\
Lycospora pusilla & 271 & 2 \\
Punctatisporites aerarius & 1 & 3 \\
Velamisporites minor & 7 & 7 \\
Simple apiculate spores & 10 & 3 \\
Simple smooth spores & 7 & \\
Botryococcus braunii & 11 & \\
\hline
\end{tabular}


intertemporal bone absent; pterygoids sutured along midline and united with basipterygoid processes; no interpterygoid vacuities.

\section{Spathicephalus marsdeni sp. nov.}

Figure 2

LSID. urn:lsid:zoobank.org:act:5314A8BA-EB01-46CD-84C0FD114210CB0C

Derivation of name. Named in honour of John Marsden who discovered the new locality and helped with the recovery of the material.

Holotype. National Museums Scotland NMS G 2015.37.1 skull.

Other material. NMS G 2015.37.2 right mandible.

Type locality and horizon. East Fife coast, between St Andrews and Fife Ness. Precise locality information is available from National Museums Scotland. Anstruther Formation, Strathclyde Group; tessellatus-campyloptera (TC) palynozone (from the upper part of this zone); Asbian, Visean, Mississippian (336-335 Ma).

Diagnosis. Postparietals half the length of the parietals. Prefrontal forms entire medial border of the antorbital vacuity and bears a swelling on its posterolateral edge that separates the orbit from the antorbital vacuity. Orbits and antorbital vacuities occupy approximately half the length of the skull. Snout short. Retroarticular process present.

Remarks. The new material is assigned to the genus Spathicephalus on the basis of skull shape, proportions of the skull table, relative positions of the jaw articulation and occiput, the narrow interorbital region and the frontals entering the orbit margin, preventing contact between the prefrontal and postfrontal. S. marsdeni is half the size of the younger species S. mirus (Beaumont \& Smithson 1998) and S. pereger (Baird 1962) from the Serpukhovian (Namurian) of Scotland and Nova Scotia. The proportions of the skull are also different with a shorter snout and relatively longer skull table (cf. Fig. 3C, D). The orbits and antorbital vacuities occupy a much larger area of the skull roof, representing approximately $43 \%$ of the total skull length, compared with approximately $28 \%$ in S. mirus. The prefrontal is similar in shape and position to those of baphetids (cf. Fig. 3C, E, F) in contrast to S. mirus (cf. Fig. 3C, D) which lacks the prefrontal swelling. This suggests that an elongate prefrontal with a mesial swelling separating the orbit from the antorbital vacuity is the plesiomorphic condition. The proportions of the nasals, frontals, parietals and postparietals, which become progressively shorter posteriorly (cf. Fig. 3A, B with Fig. 3C, E, F), are similar in S. marsdeni and baphetids, whereas in S. mirus the parietals and postparietals are of a similar length (cf. Fig. 3C, D). In S. marsdeni and baphetids the pattern of bones behind the orbit is similar and the post frontal prevents the postorbital contacting the parietal. In S. mirus the postfrontal is much reduced allowing a postorbital-parietal suture (cf. Fig. 3C-F). These differences in the structure and pattern of bones in the skull roof make it unlikely that the differences in proportions between S. marsdeni and S. mirus are due simply to allometric growth. In S. marsdeni the bases of teeth are preserved in the posterior half of the dentary and we estimate there were spaces for approximately 80 teeth. This compares with $110-120$ in S. mirus (Beaumont \& Smithson 1998).

\section{RESULTS}

\section{Description of fossil bed}

The new fossil bed is a thin ferroan dolostone $9 \mathrm{~cm}$ thick (Fig. 4A). The bed base comprises two partially fragmented centimetre-thick stromatolitic layers that are interbedded with, and overlain by, micritic ferroan dolostone with a mottled appearance and irregular subtle contacts between patches with marginally different grain sizes. Complete ostracod carapaces, shell fragments and some quartz grains are present. A distinctive centimetre-thick dark layer occurs in the middle of the bed (Fig. 4B) comprising clear silt- to granule-sized predominantly lithic clasts within a clay matrix. The lithic clasts are ferroan dolostone and are associated with abundant shell fragments (also dolomitized), clasts of organic matter, some phosphatic bone and teeth material, and rare quartz grains. This layer is overlain by more dolostone with an irregular mottled character that passes up into clear identifiable clasts, initially solely ferroan dolomite up to medium and large pebble-sized, in association with shell fragments, other lithics and clasts of organic matter, all in a clay matrix. There is potentially some grading in this flow with this more diverse clast assemblage in the top 5-10 $\mathrm{mm}$. The main fossil finds are also concentrated at the top and are essentially restricted to a discrete layer on the bedding plane. Within the bed, vertebrate material is comparatively rare and typically appears only a few millimetres to $<100 \mu \mathrm{m}$ in size. Pyrite is present as framboids and in euhedral form.

\section{Interpretation}

The palynological analysis of the mudstone samples from immediately below the fossil bed (see Palaeoenvironment 
A
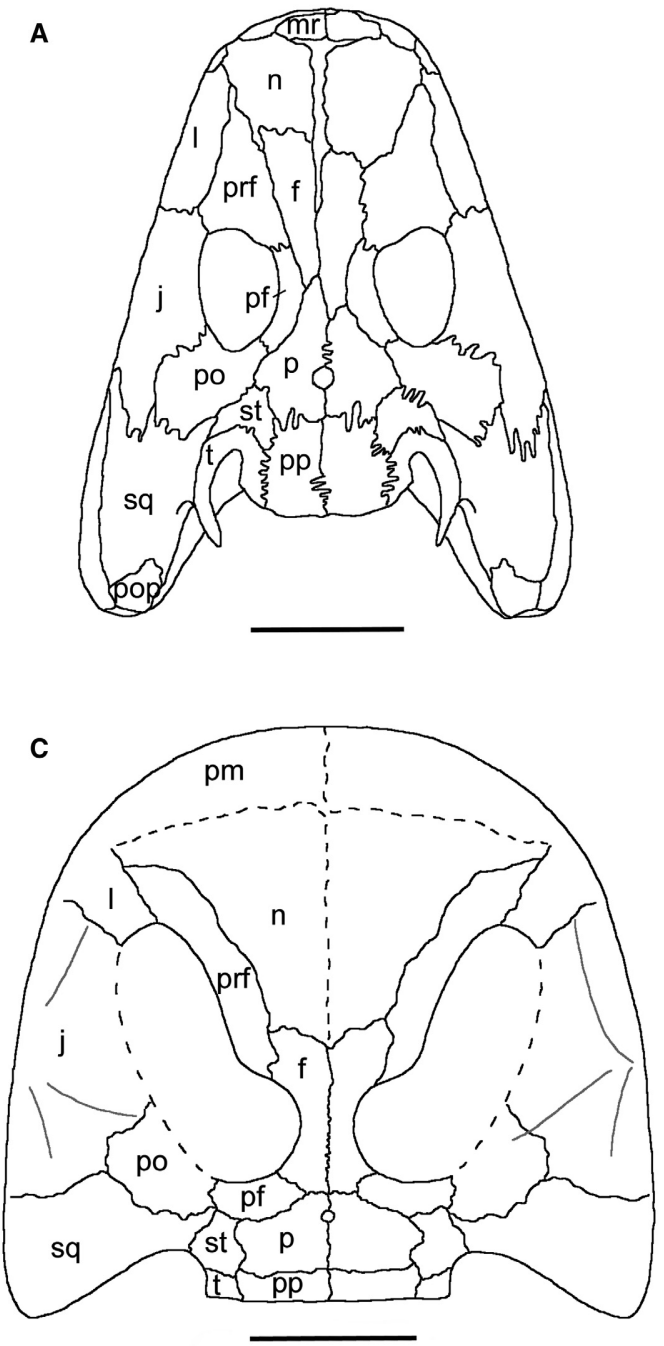

E

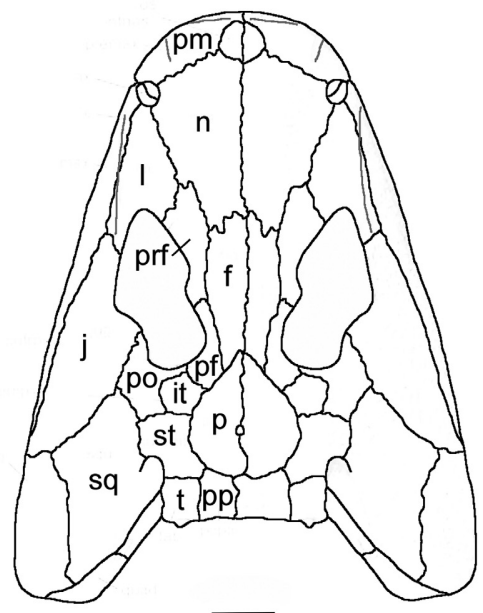

B
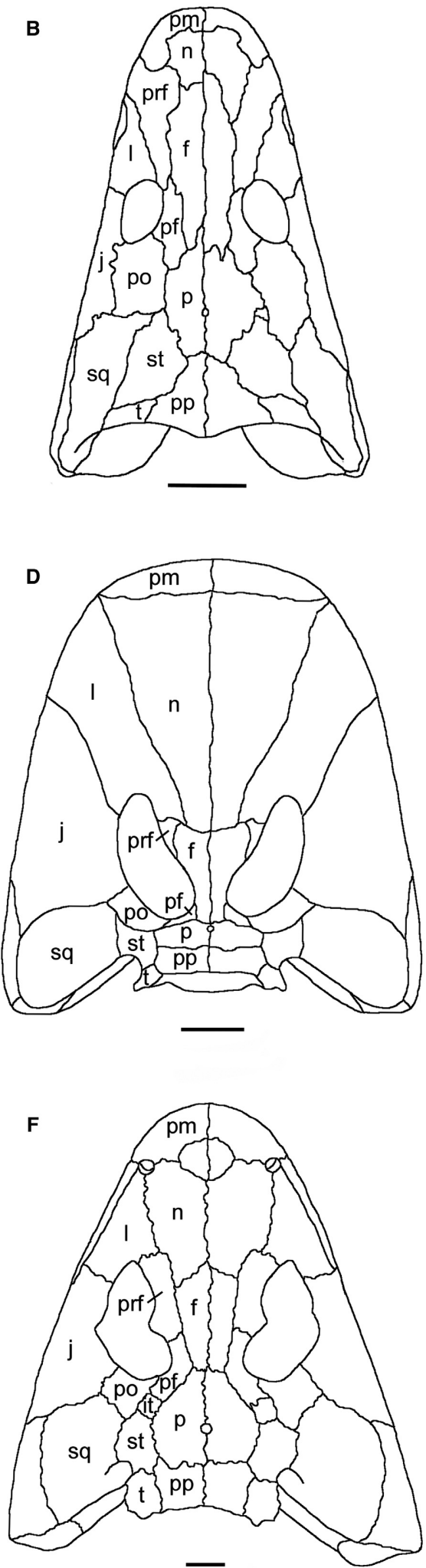

FIG. 3. Outline reconstructions of tetrapod skulls in dorsal view. A, Acanthostega gunnari. B, Greerepeton burkemorani. C, S. marsdeni. D, S. mirus. E, Baphetes kirkbyi. F, Loxomma acutirhinus. (All except C after Clack \& Milner 2015.). Abbreviations: f, frontal; it, intertemporal; j, jugal; 1, lacrimal; mr, median rostral; n, nasal; p, parietal; pf, postfrontal; pm, premaxilla; po, postorbital, pop, preopercular; pp, postparietal; prf, prefrontal; st, supratemporal; sq, squamosal; t, tabular. All scales bars represent $30 \mathrm{~mm}$. 

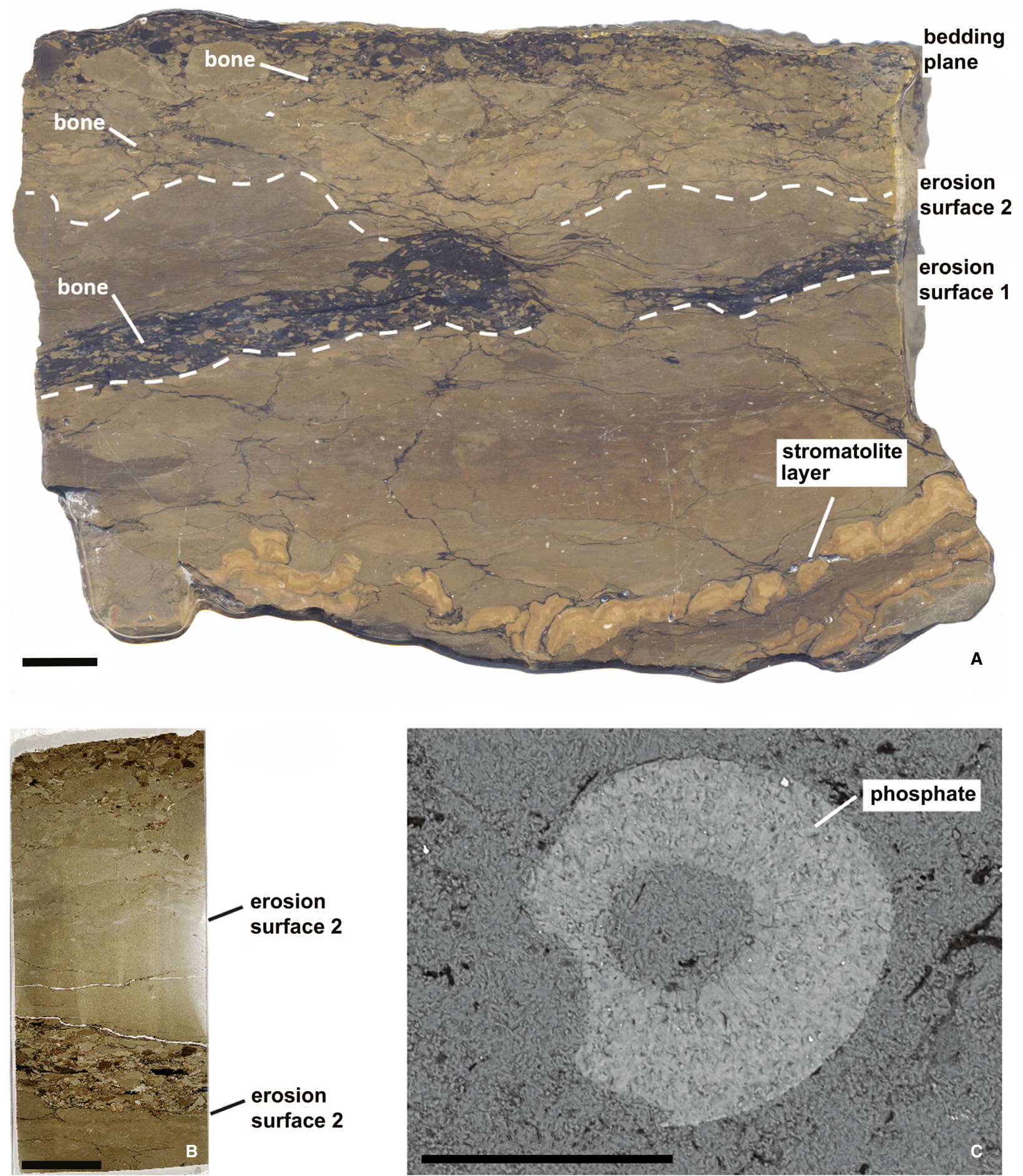

FIG. 4. Lithology of the fossil bed. A, polished cut surface of the bed showing a stromatolite layer at the base and the main fossil layer at the top. B, polished thin section showing detail of the erosion surfaces and the clast-bearing layer. C, SEM image of bone fragment in dolomite. Scale bars represent $10 \mathrm{~mm}(\mathrm{~A}, \mathrm{~B}) ; 100 \mu \mathrm{m}(\mathrm{C})$. Colour online.

below) indicates that they were deposited in a large, stratified, freshwater lake. The presence of the overlying micritic dolostone and associated basal stromatolitic layers forming the fossil bed suggests that salinity increased, possibly to hypersaline levels. Dolomite precipitation requires high levels of calcium and magnesium ions, with low dissolved-sulphate levels (Baker \& Kastner 1981). Marine waters are a key source for the ions required but 
lake dolostones can form due to evaporative concentration of groundwaters creating hypersaline brines (e.g. De Deckker \& Last 1988; Pérez et al. 2002). The small crystalline character of the dolomite suggests a primary origin, although a diagenetic origin cannot be ruled out as all shell material is also ferroan dolomite. The mottled character of the dolostones above the stromatolites suggests soft-sediment deformation of a soupy, predominantly mud substrate. The distinctive clast-bearing layer indicates erosion, reworking and transport of material. Given the range of clast sizes, lack of sorting and overall matrix support transport by a debris flow is proposed with the ferroan dolomite clasts and shell fragments probably derived from deposits elsewhere in the water body. Clast shapes indicate that consolidated and plastic lithic clasts were transported. A further phase of carbonate mud deposition was disrupted by a second flow that also disturbed the underlying sediment. The grading observed and the abundance of the vertebrate and tetrapod fauna found on the bedding plane indicates concentration in the transporting flow, although some of the material remained associated. As the lake water chemistry changed, from freshwater to strongly evaporitic, the environment could have become hostile to the aquatic fauna.

The spore assemblage and the age of the fossil horizon

There has been significant palynological work done on the early Carboniferous sequences across the Midland Valley of Scotland and particularly in the Fife succession. This was summarized by Neves et al. (1973), discussed by Owens et al. (2005) and has resulted in the definition of a series of palynological zones. Each new zone was defined by a spore species or combination of spore species that are not present in older sediments. For example, Lycospora pusilla defines the $\mathrm{Pu}$ (pusilla) zone at the base of the Visean. Often, the defining spore species of a zone are also found in younger zones but never vice versa. However, as the spores are present in almost entirely non-marine sediments with occasional incursions, the usual problem of correlation to the international timescale remains.

All the taxa recovered from Fife 1 are listed and figured in Smithson et al. (2017). The assemblage is dominated by Lycospora pusilla, which shows that the age is $\mathrm{Pu}$ spore zone or younger (Table 1). The presence of Knoxisporites stephanephorus and K. triradiatus indicates the TS spore zone or younger. The samples have many specimens of Schulzospora camplyoptera and Velamisporites tesellatus. These are the nominate taxa for the overlying TC zone. However, in the Scottish Borders there is only a single section, from Marshall Meadows borehole, which yields continuous palynological recovery across the Pu-TS-TC zone boundaries (Neves et al. 1973). This shows other spore inceptions that occur in the basal TC zone of taxa that are also present in the Fife samples. These are Crassispora aculeata, Waltzispora planiangulata, Verrucosisporites baccatus and Tricidarisporites dumosus.

The succeeding zone is NM (Riastrickia nigra - Triquitrites marginatus) which was split by Owens et al. (2005), into DP (Tripartites distinctus - Murospora parthenopia) and ME (Murospora margodentata - Rotaspora ergonulii) subzones. No taxa from these younger zones/subzones were found in the samples investigated. The taxa which define these younger zones include some very distinctive forms including auriculate spores with prominent radial extensions (Tripartites and Triquitrites) or cingulate spores that are distinguished by a very wide equatorial thickening (Monilospora) or equatorial extensions.

It is also possible to resolve the position of the samples within the TS zone as there are a number of inceptions within the zone. These include Felixites playfordii (essentially a variant of $F$. pollenisimilis) and suggest a position within the upper part of the zone. Also present are specimens similar to Claytonispora variabilis which is recorded from Fife (Owens et al. 2005) at the TC-NM boundary. The three specimens from the Fife 1 sample have sculpture entirely typical of that described by Hibbert \& Lacey (1969) except that they are all single discrete elements and not present in twos and threes above a single basal element. It looks like the sculpture present on the specimen described as Claytonispora rarisetosa as figured by Playford \& Melo (2012). This spore assemblage data shows that the age is TC zone, and from the upper part of that zone. Correlation with the British Carboniferous stages (Riley 1993) indicates an Asbian age.

\section{Palaeoenvironment}

The significant characteristic of the Fife 1 assemblage is the overwhelming abundance of Lycospora pusilla microspores. These are known in situ (as reviewed by Bek 2012) from the cones of large tree-sized lycopods such as Lepidodendron. However, the megaspore fraction shows no corresponding abundance of lycopod megaspores apart from rare isolated spines. Also, very rare are phytoclasts (i.e. plant debris). This is interpreted as an assemblage that has been selectively sorted by transport that has left any coarser material behind. Both samples contained AOM which forms from microbial production in a stratified water body. There is also 3\% Botryococcus in the assemblage, an alga that lives in bodies of still fresh water (Batten \& Grenfell 1996). This suggests a depositional environment for these mudstone samples of a freshwater lake deep enough to be stratified and wide 
enough to selectively sort out the larger spores and plant debris.

\section{DISCUSSION}

The discovery of S. marsdeni in the Asbian of Fife extends the range of the Spathicephalidae by approximately eight million years. It also extends the record of the baphetoids into the Asbian and indicates that the split into baphetids and spathicephalids must have occurred much earlier. In most phylogenies of early tetrapods, the baphetoids are placed immediately below crown tetrapods (Clack 2012). The most recent analysis (Clack et al. 2016) incorporates new taxa from the Tournaisian of Scotland, and reveals that this fauna probably included members of the tetrapod crown. This suggests that the earliest baphetoids are at least as old as these Tournaisian forms and that potentially the clade has a history that encompasses the entire Carboniferous.

This discovery also demonstrates that the unique antorbital vacuities of baphetoids (Milner et al. 2009) were well developed in the earliest-known members of the group. Apart from representing major openings in the preorbital roof of the skull, their function remains unknown. It has been suggested that the antorbital vacuities housed either salt glands or electrosensory organs, or may have been a bulging hole for jaw closing muscles (see discussion in Clack 2012). Recently, Witzmann \& Werneburg (2017) suggested that the vacuities may be a 'mirror-inverted' condition of the anteriorly extended interpterygoid vacuities of stereospondyls and accommodated bulging jaw musculature. This is similar to the suggestion first made by Beaumont (1977), although how it could apply in a skull as flattened as that of a spathicephalid is not clear. Whatever their function, the antorbital vacuities were retained by the baphetoids for at least $35 \mathrm{myr}$, from this their first appearance in the Asbian until their last in the late Pennsylvanian (Clack \& Milner 2015).

S. marsdeni is one of a number of tetrapods found in the late Visean and early Serpukhovian that lacked the large marginal teeth and palatal fangs of other early tetrapods and instead had a marginal dentition comprising many small, uniform teeth. The others are Sigournea from the Asbian of Iowa (Bolt \& Lombard 2006); Doragnathus (Smithson 1980) and the adelogyrinids (Andrews \& Carroll 1991) from the Asbian and Serpukhovian of Scotland; and S. mirus (Beaumont \& Smithson 1998) and S. pereger (Baird 1962) from the Serpukhovian of Scotland and Nova Scotia. This pattern of dentition is relatively common in the Scottish fauna and has been found at 9 of the 13 late Mississippian sites (Smithson 1985). These unrelated (Clack et al. 2016) multi-toothed forms were all probably aquatic tetrapods and had either small, poorlydeveloped limbs (Smithson \& Clack 2013) or were limbless (Andrews \& Carroll 1991). Among the extant fauna, cryptobranchid salamanders have a broad-headed skull and numerous small teeth and use suction feeding to capture small aquatic prey (Heiss et al. 2013). It is possible that the spathicephalids used a similar feeding strategy and, if so, are the earliest known group of tetrapods to develop an alternative to jaw grasping. These ideas have been discussed elsewhere (Beaumont \& Smithson 1998), and could be tested by biomechanical analysis of the spathicephalid skull. Furthermore, given the greater age of S. marsdeni and its apparent retention of plesiomorphic characters compared to S. mirus, there may be some divergence in feeding system function between the two species, raising the possibility the $S$. marsdeni might eventually be able to provide insight into the evolution of the more derived morphology of $S$. mirus.

S. marsdeni formed part of an extensive aquatic vertebrate fauna that included actinopterygians, gyracanthids, lungfish, rhizodonts and rare elasmobranchs. These are currently represented mainly by dissociated and fragmentary scales, teeth and spines, although two lungfish specimens are represented by partly articulated material. Other tetrapod remains have been found including isolated vertebrae and ribs, pectoral girdle elements, limb bones as well as further cranial remains. This material is currently in Mr Marsden's private collection and should become available for detailed study in due course.

The depositional environment of the new site in Fife was likely to have been a delta plain with lakes and small mires. The palynological analysis of the samples taken from the siltstone beneath the fossil bed (Fig. 1) suggests it was deposited in a freshwater lake environment, deep enough to be stratified and wide enough to selectively sort out the larger spores and plant debris. Sedimentological analysis of the overlying fossil bed suggests that salinity later increased, possibly to hypersaline levels, and eventually it became hostile to the aquatic fauna.

The discovery of a spathicephalid in the Asbian of Fife provides further evidence of the rapid diversification of early tetrapods following the end-Devonian extinction event (Clack et al. 2016). It adds to growing evidence that the equatorial latitudes of Laurussia were a key area for tetrapod evolution during the Carboniferous (McKerrow et al. 2000). It is also another example of recent finds that have suggested a much earlier origin for other Carboniferous tetrapod groups than previously envisaged (Clack et al. 2016). Some taxa may even have crossed the Devonian-Carboniferous boundary (Anderson et al. 2015). It is anticipated that further study of the material so far recovered from the new site and continued collecting will add to our knowledge of tetrapod diversity and feeding specializations in the late Visean. 
Acknowledgements. This work was funded by NERC consortium grants NEJ021067/1 (BGS), NE/J022713/1 (Cambridge), NE/ J020729/1 (Leicester), NE/J020621/1 (NMS), and NE/J021091/1 (Southampton). We thank Paul Bancks from The Crown Estate office in Edinburgh for permission to collect from the Fife foreshore, John Marsden and NMS staff Nick Fraser, Andrew Ross, Yves Candela, Sarah Stewart, Vicen Carió and Laura Romero for collecting the material, and Janet Sherwin for assistance with the sedimentological analysis. Shir Akbari prepared the palynological samples. We thank Jason Head for discussion, and Kenneth Angielczyk, Sally Thomas and three anonymous referees for their helpful comments on the manuscript. Michael Browne and David Millward publish with the permission of the Executive Director, British Geological Survey (NERC).

\section{DATA ARCHIVING STATEMENT}

This published work and the nomenclatural act it contains, have been registered in ZooBank: http://zoobank.org/References/E3C21A58-CA5A4EBA-9241-605D63DAD113

Data for this study are available in the Dryad Digital Repository: https://doi.org/10.5061/dryad.q6cg2

Editor. Kenneth Angielczyk

\section{REFERENCES}

ANDERSON, J. S., SMITHSON, T. R., MANSKY, C. F., MEYER, T. and CLACK, J. A. 2015. A diverse tetrapod fauna at the base of Romer's Gap. PLoS One, 10, e0125446.

ANDREWS, S. M. and CARROLL, R. L. 1991. The Order Adelospondyli: Carboniferous lepospondyl amphibians. Transactions of the Royal Society of Edinburgh, 82, 239-275.

BAIRD, D. 1962. A rhachitomous amphibian, Spathicephalus, from the Mississippian of Nova Scotia. Breviora, 157, 1-9.

BAKER, P. A. and KASTNER, M. 1981. Constraints on the formation of sedimentary dolomite. Science, 213, 214-216.

BATTEN, D. J. and GRENFELL, H. R. 1996. Botryococcus. 205-214. In JANSONIUS, J. and McGREGOR, D. C. (eds). Palynology: principles and applications. American Association of Stratigraphical Palynologists Foundation, 1330 pp.

BEAUMONT, E. H. 1977. Cranial morphology of the Loxommatidae (Amphibia: Labyrinthodontia). Philosophical Transactions of the Royal Society of London B, 280, 29-101.

— and SMITHSON, T. R. 1998. The cranial morphology and relationships of the aberrant Carboniferous amphibian Spathicephalus mirus Watson. Zoological Journal of the Linnean Society, 122, 187-209.

BEK, J. 2012. A review of the genus Lycospora. Review of Palaeobotany \& Palynology, 174, 122-135.

BOLT, J. R. and LOMBARD, R. E. 2006. Sigournea multidentata, a new stem tetrapod from the Upper Mississippian of Iowa, USA. Journal of Paleontology, 80, 717-725.

- McKAY, R. M., WITZKE, B. J. and McADAMS, M. P. 1988. A new Lower Carboniferous tetrapod locality in Iowa. Nature, 333, 355-356.
CLACK, J. A. 2012. Gaining ground: the origin and evolution of tetrapods, 2nd edn. Indiana University Press, 523 pp.

— and MILNER, A. R. 2015. Handbook of paleoherpetology part 3A1 Basal Tetrapoda. Friedrich Pfeil, Munchen, 93 pp.

- BENNETT, C. E., CARPENTER, D. K., DAVIES, S. J., FRASER, N. C., KEARSEY, T. I., MARSHALL, J. E. A., MillWARD, D., OTOO, B., REEVES, E. J., ROSS, A. J., RUTA, M., SMITHSON, K. Z., SMITHSON, T. R. and WALSH, S. A. 2016. Phylogenetic and environmental diversity revealed for Tournaisian tetrapods. Nature Ecology \& Evolution, 1, 0002.

COPE, E. D. 1875. Checklist of North American Batrachia and Reptilia. Bulletin of the United States National Museum, 1, $1-95$.

DE DECKKER, P. and LAST, W. M. 1988. Modern dolomite deposition in continental, saline lakes, western Victoria, Australia. Geology, 16, 29-32.

FORSYTH, I. H. and CHISHOLM, J. I. 1977. The geology of East Fife. Explanation of parts of one-inch Scotland sheets 41 and 49. Memoirs of the Geological Survey of Great Britain, HMSO.

GOODRICH, E. S. 1930. Studies on the structure and development of vertebrates. Macmillan, $882 \mathrm{pp}$.

HEISS, E., NATCHEV, N., GUMPENBERGER, M., WEISSENBACHER, A. and VAN WASSENBERGH, S. 2013. Biomechanics and hydrodynamics of prey capture in the Chinese giant salamander reveal a high-performance jaw-powered suction feeding mechanism. Journal of the Royal Society Interface, 10, 20121028.

HIBBERT, F. A. and LACEY, W. S. 1969. Miospores from the Lower Carboniferous Basement Beds in the Menai Straits region of Caernarvonshire, north Wales. Palaeontology, 12, 420-440.

McKerRoW, W. S., MAC NIOCAILL, C., AHLBERG, P. E., CLAYTON, G., CLEAL, C. J. and EAGAR, R. M. C. 2000. The Late Palaeozoic relations between Gondwana and Laurussia. Geological Society of London Special Publication, 179, 9-20.

MILNER, A. C. and LINDSAY, W. 1998. Postcranial remains of Baphetes and their bearing on the relationships of the Baphetidae (=Loxommatidae). Zoological Journal of the Linnean Society, 122, 211-235.

- MilneR, A. R. and WALSH, S. A. 2009. A new specimen of Baphetes from Nýřany, Czech Republic and the intrinsic relationships of the Baphetidae. Acta Zoologica, 90, 318334.

NEVES, R., GUEINN, K. J., CLAYTON, G., IOANNIDES, N. S., NEVILLE, R. S. W. and KRUSZEWSKA, K. 1973. Palynological correlations within the Lower Carboniferous of Scotland and Northern England. Transactions of the Royal Society of Edinburgh, 69, 23-70.

OWENS, B., McLEAN, D., SIMPSON, K. R. M., SHELL, P. M. J. and ROBINSON, R. 2005. Reappraisal of the Mississippian palynostratigraphy of the East Fife coast, Scotland, United Kingdom. Palynology, 29, 23-47.

PATON, R. L., SMITHSON, T. R. and CLACK, J. A. 1999. An amniote-like skeleton from the early Carboniferous of Scotland. Nature, 398, 508-513. 
PÉREZ, A., LUZÓN, A., ROC, A. C., SORIA, A. R., MAYAYO, M. J. and SÁNCHEZ, J. 2002. Sedimentary facies distribution and genesis of a recent carbonate-rich saline lake: Gallocanta Lake, Iberian Chain, NE Spain. Sedimentary Geology, 148, 185-202.

PLAYFORD, G. and MELO, J. H. G. 2012. Miospore palynology and biostratigraphy of Mississippian strata of the Amazonas Basin, northern Brazil. American Association of Stratigraphic Palynologists Contribution Series, 47, 1-201.

RILEY, N. J. 1993. Dinantian (Lower Carboniferous) biostratigraphy and chronostratigraphy in the British Isles. Journal of the Geological Society of London, 150, 427-446.

SMITHSON, T. R. 1980. A new labyrinthodont amphibian from the Carboniferous of Scotland. Palaeontology, 23, 915923.

1985. Scottish Carboniferous amphibian localities. Scottish Journal of Geology, 21, 123-142.

— and CLACK, J. A. 2013. Tetrapod appendicular skeletal elements from the Early Carboniferous of Scotland. Comptes Rendus Palevol, 12, 405-417.

-WOOD, S. P., MARSHALL, J. E. A. and CLACK, J. A. 2012. Earliest Carboniferous tetrapod and arthropod faunas from Scotland populate Romer's Gap. Proceedings of the National Academy of Sciences, 109, 4532-4537.

BROWNE, M. A. E., DAVIES, S. J., MARSHALL, J. E. A., Millward, D., WAlSh, S. A. and CLACK, J.
A. 2017. Data from: A new Mississippian tetrapod from Fife, Scotland, and its environmental context. Dryad Digital Repository. https://doi.org/10.5061/dryad.q6cg2

THULBORN, L., WARREN, A., TURNER, S. and HAMLEY, T. 1996. Early Carboniferous tetrapods in Australia. Nature, 381, 777-780.

WATERS, C. N., SOMERVIlle, I. D., JONES, N. S., CLEAL, C. J., COLLINSON, J. D., WATERS, R. A., BESLEY, B. M., DEAN, M. T., STEPHENSON, M. H., DAVIES, J. R., FRESHNEY, E. C., JACKSON, D. I., MitChELL, W. I., POWELL, J. H., BARCLAY, W. J., BROWNE, M. A. E., LEVERIDGE, B. E., LONG, S. L. and McLEAN, D. 2011. A revised correlation of Carboniferous rocks in the British Isles. Geological Society of London, $186 \mathrm{pp}$.

WATSON, D. M. S. 1929. The Carboniferous Amphibia of Scotland. Palaeontologia Hungarica, 1, 219-252.

WITZMANN, F. and WERNEBURG, I. 2017. The palatal interpterygoid vacuities of temnospondyls and the implications for the associated eye- and jaw musculature. The Anatomical Record, 300, 1240-1269.

WOOD, S. P., PANCHEN, A. L. and SMITHSON, T. R. 1985. A terrestrial fauna from the Scottish Lower Carboniferous. Nature, 314, 768-770. 